\title{
Ferritin - The key model inflammatory marker in diabetic and non-diabetic COVID-19
}

\author{
Mukesh Kumar', Bindu $\mathrm{CM}^{2}$, Shyam $\mathrm{AC}^{3}$, Reena $\mathrm{R}^{4}$ \\ ${ }^{1}$ Assistant Professor, ${ }^{2}$ Professor, ${ }^{4}$ Associate Professor, Department of Biochemistry, ${ }^{3}$ Professor, Department of \\ Community Medicine, Rajarajeswari Medical College and Hospital, Bengaluru, Karnataka, India
}

Background: Diabetics exhibit elevated serum ferritin level when compared to non-diabetic counterpart, indicates impact of its association with coronavirus disease 2019 (COVID-19) infection and disease progression. Ferritin is a key mediator of immune dysregulation through direct immunosuppression contributing to cytokine storm resulting in fatal outcome in COVID-19. Aims and Objectives: This study aims to estimate serum ferritin in diabetic (cases) and non-diabetic (controls) COVID-19 patients and its correlation with their diabetic profile (FBS, PPBS, RBS, and $\mathrm{HbA} 1 \mathrm{C}$ ). Materials and Methods: A retrospective case-control study conducted at Rajarajeswari Medical College and Hospital, Bengaluru, for a period of 8 months among diabetic and non-diabetic COVID-19 patients. Results: The study population consisted of 957 individuals, out of them, 425 patients were type 2 diabetes mellitus and 532 were non-diabetic COVID-19-positive patients (controls). Diabetic profile parameters (FBS, PPBS, RBS, and $\mathrm{HbA} 1 \mathrm{c})$ and serum ferritin were significantly $(\mathrm{P}<0.05)$ high in cases as compared to controls. Among diabetic COVID-19, the glycated hemoglobin and serum ferritin showed a significantly positive correlation $(r=0.55)$ with serum ferritin (mean $=648.98 \pm 320.48$ ). Conclusion: Hyperferritinemia is more prevalent in diabetic COVID-19 individuals. Serum ferritin can be considered as a valuable biomarker to screen the diabetic and non-diabetic for the presence of hyperinflammation and to predict severity of COVID-19 infection so that it will help the clinician for proper management.

\section{Access this article online}

Website:

http://nepjol.info/index.php/AJMS DOI: 10.3126/ajms.v12i12.39717

E-ISSN: 2091-0576

P-ISSN: 2467-9100

Copyright (c) 2021 Asian Journal of Medical Sciences

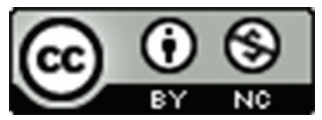

This work is licensed under a Creative Commons Attribution-NonCommercial 4.0 International License.

Key words: Type 2 diabetes mellitus; $\mathrm{HbA}_{\mathrm{C}}$; Serum ferritin; Severe acute respiratory syndrome coronavirus-2

\section{INTRODUCTION}

In December 2019, a sequence of pneumonia cases of unknown cause was reported in Wuhan, Hubei, China. Later on, the novel coronavirus was isolated from respiratory tract samples named as severe acute respiratory syndrome coronavirus-2 (SARS-CoV-2). The new virus swiftly unfolds globally ensuing in a pandemic by the WHO on March 11, $2020 .{ }^{1}$

The disease due to SARS-CoV- 2 is referred as coronavirus disease 2019 (COVID-19) tiers from moderate acute respiratory illness to extreme pneumonia with respiratory failure, acute respiratory distress syndrome, and septic shock. ${ }^{2}$ As per the WHO, the COVID-19 virus infects people of all ages. Older adults and those with underlying medical comorbidities, such as hypertension, diabetes, chronic lung disease, cardiovascular disease, chronic kidney disease, and cancer are at higher risk of severity of illness. ${ }^{3,4}$

Diabetes is a metabolic disorder characterized by hyperglycemia from defects in insulin secretion, insulin action, or both. ${ }^{5}$ People with type 2 diabetes mellitus develop characteristic microvascular and macrovascular complications such as retinopathy, nephropathy, and neuropathy. Complications due to diabetes are a major cause of disability which reduces quality of life and leads to death. Compared to non-diabetic, diabetics have an immunocomprised status, which tends to reduce their resistance and make them more vulnerable to corona like infections as well as consequent complications. ${ }^{6}$ 
The prevalence of diabetes in patients with COVID-19 depends on duration and characteristics of study population. In a multicenter study with 1099 patients hospitalized with COVID-19 illness in China, the overall prevalence of diabetes was $7.4 \% .^{7}$ In a meta-analysis of seven studies including 1576 patients from China, diabetes was the second most common comorbidity following hypertension and was present in $9.7 \%$ of patients. ${ }^{8}$ In another meta-analysis of 21 studies mainly from China, hypertension and diabetes were the foremost prevalent comorbidities present in $15.6 \%$ and $7.7 \%$, respectively, among 47,344 patients with COVID-19. ${ }^{9}$

Studies suggest that the low-grade chronic inflammation along with the hypercoagulable state in diabetes may promote the cytokine storm, a complication of severe COVID-19 which is characterized by excessive production of inflammatory cytokines (IL-6, IL-10, and TNF- $\alpha$ ). ${ }^{10}$ Ferritin is a key mediator of immune dysregulation through direct immunosuppression contributing to cytokine storm resulting in fatal outcome in COVID-19. ${ }^{11}$ Diabetic exhibits elevated serum ferritin level when compared to nondiabetic counterpart indicates impact of its association with infection and disease progression. ${ }^{12}$

Approximately 5.1 million people aged between 20 and 79 years died from diabetes accounting for $8.4 \%$ of global all-cause mortality in this age group. ${ }^{13}$ In India, 65.1 million in the age group of $20-79$ have diabetes $(8.56 \%)$ and expected to rise to 109 million by the year $2035 .{ }^{14}$ Diabetes is associated with increased mortality rate in patients with COVID-19 and is considered as a major risk factor for COVID-19 infection. As per the study done by American Diabetic Association among the people with diabetes COVID-19, the mortality rate was $7.3 \%$. Two other conditions that are common in those with diabetes were also associated with higher mortality rates: $10.5 \%$ for cardiovascular disease and $6.0 \%$ for hypertension. Diabetics experience higher rates of mortality and are less likely to be discharged when compared with nondiabetic patients. ${ }^{15}$ Because mortality rates were not stratified by age, it is not clear how much of the excess risk in people with these conditions was independently related to age. The symptoms of COVID-19, including fever, shortness of breath, and cough, were mostly reported in diabetic patients than in non-diabetic patients, while chest pain, sore throat, and decreased sense of smell and taste were more common in non-diabetic COVID-19 patients. In a study conducted in China, fever, dry cough, and fatigue were the most common symptoms in diabetic COVID-19 patients ${ }^{16}$ and another study showed cough and fever as the most common symptoms in these patients. ${ }^{17}$

To the best of our knowledge, there is a paucity of literature, especially from India showing direct evidence of relation between diabetes mellitus and ferritin in COVID-19. This study is the first of its kind in South Indian population with large sample size. This research was designed to enlighten this path and to compare serum ferritin in diabetic (cases) and non-diabetic (controls) COVID-19 patients and the association of elevated serum ferritin level with diabetic profile (glycated hemoglobin, FBS, PPBS, and RBS) in type 2 diabetes mellitus.

\section{Aims and objectives}

The aims of the study were as follows:

1. To estimate and correlate serum ferritin in diabetic (cases) and non-diabetic (controls) COVID-19 patients

2. To correlate the diabetic profile (FBS, PPBS, RBS, and $\mathrm{HbA1C}$ ) with ferritin in diabetic (cases) and nondiabetic (controls) COVID-19 patients.

\section{MATERIALS AND METHODS}

\section{Study design}

The study was pre-approved by the Institutional Ethics Committee for the final permission. This case-control retrospective study was conducted at Rajarajeswari Medical College and Hospital, Bengaluru, for a period of 8 months (May 2020-December 2020). Type 2 diabetes mellitus and non-diabetic patients, irrespective of the gender, in the age group of 18-75 years, admitted at Rajarajeswari Medical College and Hospital, diagnosed as COVID-19 positive following COVID-19 RT-PCR test was enrolled as cases and controls, respectively.

\section{Inclusion criteria}

Type 2 diabetes mellitus patients, irrespective of diabetic control, who tested positive for COVID-19, with or without diabetic complications and with or without antidiabetic treatment, were the study cases.

\section{Exclusion criteria}

(1) Type 1 diabetes mellitus and (2) both cases and controls with a history of diseases which alter the serum ferritin levels such as hemochromatosis, chronic alcoholics, chronic inflammatory conditions like SLE/rheumatoid arthritis, hepatitis, history of repeated blood transfusions, iron deficiency anemia, hypothyroidism, and chronic kidney disease were excluded from the study.

\section{Sample collection and processing}

After obtaining informed consent from study subjects, under all aseptic precautions, $2 \mathrm{ml}$ of venous blood sample was collected in fluoride EDTA tube in fasting and postprandial state and $5 \mathrm{ml}$ in red capped and Lavender capped collection tubes for sr. ferritin and for HbA1c estimation, respectively. Estimation of FBS, PPBS, RBS, HbA1c, and serum ferritin was carried out. 


\begin{tabular}{|c|c|c|c|c|c|}
\hline HbA1C $\%$ range & $\mathrm{n}(\%)$ & Mean \pm SD HbA1C $\%$ & Serum ferritin $(\mathrm{ng} / \mathrm{mL})$ & Pearson's correlation r value & P-value \\
\hline $5-5.9$ & $6(1.4)$ & $5.76 \pm 0.19$ & $371 \pm 398.66$ & -0.41 & 0.19 \\
\hline $6-7.5$ & $214(50.4)$ & $6.72 \pm 0.44$ & $497.32 \pm 310.81$ & 0.57 & 0.00 \\
\hline $7.51-9$ & $116(27.3)$ & $8.1 \pm 0.44$ & $761.91 \pm 201.21$ & 0.256 & 0.004 \\
\hline $9.01-10.5$ & $39(9.2)$ & $9.5 \pm 0.38$ & $843 \pm 210.10$ & 0.25 & 0.11 \\
\hline$>10.5$ & $50(11.8)$ & $11.55 \pm 0.65$ & $918.19 \pm 281.77$ & 0.03 & 0.79 \\
\hline
\end{tabular}

\begin{tabular}{|c|c|c|c|c|}
\hline Variable & $\begin{array}{l}\text { Diabetic } \\
\text { COVID-19 } \\
\text { cases }\end{array}$ & $\begin{array}{l}\text { Non-diabetic } \\
\text { COVID-19 } \\
\text { controls }\end{array}$ & t-value & $P$-value \\
\hline Age & $52.89 \pm 14.14$ & $43.80 \pm 16.50$ & 9.01 & 0.000 \\
\hline RBS & $180.64 \pm 48.11$ & $104.63 \pm 18.63$ & 39.67 & 0.000 \\
\hline FBS & $291.86 \pm 91.54$ & $82.61 \pm 8.90$ & 46.01 & 0.000 \\
\hline PPBS & $281.38 \pm 100.64$ & $126.26 \pm 10.69$ & 41.37 & 0.000 \\
\hline $\mathrm{Hba1c}$ & $7.92 \pm 1.67$ & $4.50 \pm 0.31$ & 47.99 & 0.000 \\
\hline $\begin{array}{l}\text { Serum } \\
\text { ferritin }\end{array}$ & $648.98 \pm 320.48$ & $204.39 \pm 248.18$ & 24.18 & 0.000 \\
\hline
\end{tabular}

FBS, PPBS, and RBS were estimated by GOD-POD enzymatic method in fully automated Beckman Coulter Autoanalyzer. HbA1c was tested by BIORAD D10 system which is based on the principle of high-performance liquid chromatography. Serum ferritin was assayed by electrochemiluminescence method. Diabetic patients tested for $\mathrm{HbA1C}$ were arranged into five groups, as listed in Table 1. Reference range of FBS, PPBS, and RBS was $70-100 \mathrm{mg} / \mathrm{dl},<140 \mathrm{mg} / \mathrm{dl}$, and $70-140 \mathrm{mg} /$ $\mathrm{dl}$, respectively. Reference range of $\mathrm{HbA} 1 \mathrm{c}$ was $5-6.5 \%$, and serum ferritin $24-336 \mathrm{ng} / \mathrm{ml}$ in adult males and $11-306 \mathrm{ng} / \mathrm{ml}$ in adult females were considered.

\section{Statistical analysis}

Data were entered into MS Excel sheet and analyzed using SPSS version 20.0. The descriptive statistics, that is, all qualitative variables were presented as frequency and percentages. All quantitative variables used to correlate the serum ferritin levels between diabetic and non-diabetic groups were presented as mean and standard deviation test. Pearson's correlation test was applied to check the correlation between serum ferritin with parameters such as FBS, PPBS, and RBS among both groups. $\mathrm{p}<0.05$ was considered to be statistically significant. Pearson's $r$ varies between +1 and -1 , where +1 is a perfect positive correlation and -1 is a perfect negative correlation. Zero means that there is no linear correlation at all.

\section{RESULTS}

A total of 957 subjects were enrolled for the study consisting of 425 cases and 532 controls.

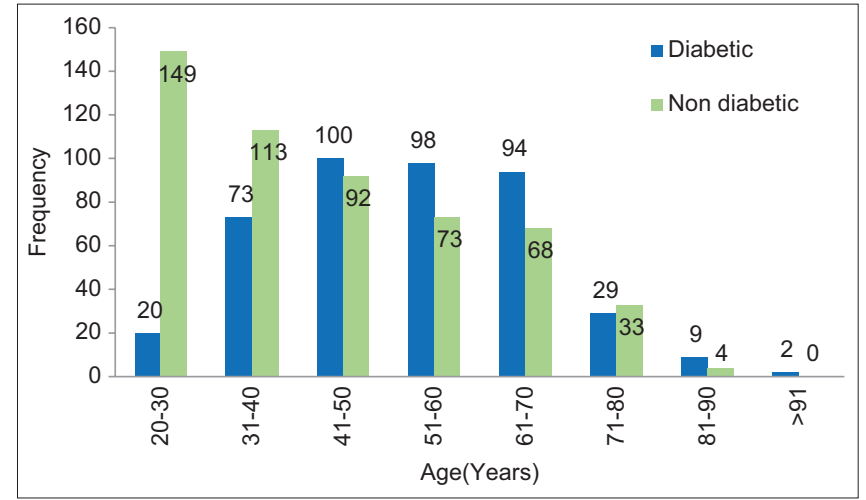

Figure 1: Age-wise distribution of entire study population

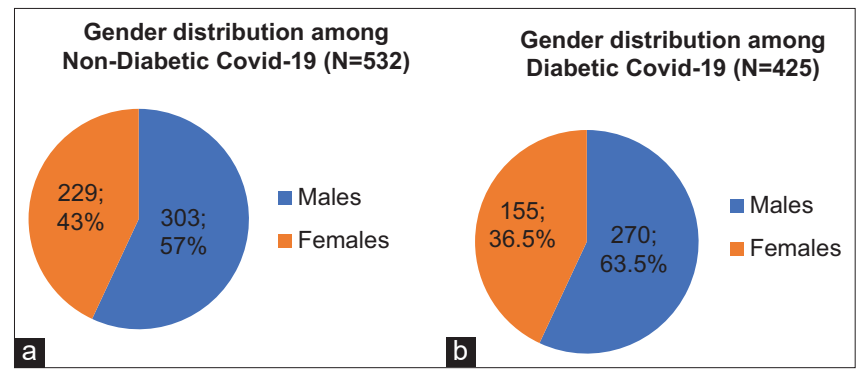

Figure 2: $(a$ and $b)$ Gender distribution of diabetic coronavirus disease 2019 (COVID-19) cases and non-diabetic COVID-19 controls

The mean age of the study participants among diabetic cases was $52.89 \pm 14$ years which is significantly higher when compared to the non-diabetic COVID-19 control group $43.80 \pm 16.50$ years (Figure 1).

Majority of the study subjects were males in both cases (57\%) and controls (63.5\%) (Figure 2).

Baseline characteristics of the entire study population are depicted in Table 2. The mean levels of diabetic profile parameters (FBS, PPBS, RBS, and HbA1c) were significantly higher $(\mathrm{P}<0.05)$ in diabetic COVID-19 cases compared to the mean values of non-diabetic COVID-19 controls. On comparison of serum ferritin levels between diabetics and non-diabetic COVID-19, it was found that mean serum ferritin level was significantly higher in cases compared to controls and the difference was statistically significant $(\mathrm{P}<0.05)$.

On comparison of gender-wise difference in the serum ferritin among both groups, it was observed that the mean 


\begin{tabular}{|c|c|c|c|c|}
\hline \multirow[t]{2}{*}{ Variable } & \multicolumn{2}{|c|}{ Serum ferritin } & \multirow[t]{2}{*}{ t-value } & \multirow[t]{2}{*}{ P-value } \\
\hline & Males & Females & & \\
\hline Diabetic COVID-19 cases & $679.11 \pm 325.20$ & $596.48 \pm 303.96$ & 7.92 & $<0.0001$ \\
\hline Non-diabetic COVID-19 controls & $274.58 \pm 273.19$ & $111.53 \pm 170.08$ & 2.57 & 0.005 \\
\hline
\end{tabular}

\begin{tabular}{|c|c|c|c|c|}
\hline Variables & Mean & $\begin{array}{l}\text { Standard } \\
\text { deviation }\end{array}$ & $\begin{array}{l}\text { Pearson's } \\
\text { correlation } \\
\text { r value }\end{array}$ & P-value \\
\hline \multicolumn{5}{|l|}{$\begin{array}{l}\text { Diabetic } \\
\text { COVID-19 } \\
\text { cases }\end{array}$} \\
\hline $\begin{array}{l}\text { Serum } \\
\text { ferritin }\end{array}$ & 648.98 & 320.48 & 0.55 & 0.00 \\
\hline $\begin{array}{l}\text { HbA1C } \\
\text { Non-diabetic } \\
\text { COVID-19 } \\
\text { controls }\end{array}$ & 7.92 & 1.67 & & \\
\hline $\begin{array}{l}\text { Serum } \\
\text { ferritin }\end{array}$ & 207.83 & 249.39 & 0.068 & 0.11 \\
\hline $\mathrm{HbA1C}$ & 4.50 & 0.31 & & \\
\hline
\end{tabular}

serum ferritin among males was higher than females in both diabetic and non-diabetic COVID-19 groups and this gender-wise difference in the mean values of serum ferritin was found to be statistically significant in both case and and control groups $(\mathrm{P}<0.05)$ (Table 3).

The correlation between glycated hemoglobin and serum ferritin was done by Pearson's correlation test and it showed a statistically significant $(\mathrm{P} \leq 0.05)$ positive correlation $(\mathrm{r}=0.55)$ in diabetic Covid-19 cases (Table 4) and (Figure 3). The correlation between serum ferritin and $\mathrm{HbA} 1 \mathrm{c}$ amongst controls showed weak positive correlation which was not statistically significant $(\mathrm{P}=0.11)$ (Table 4) (Figure 4).

Mean \pm SD value of serum ferritin level in different $\mathrm{HbA1c}$ range was measured. Mean ferritin of all the groups of glycated hemoglobin was calculated and highest mean ferritin was seen in the poorly controlled diabetic group with $\mathrm{HbA} 1 \mathrm{c}>10.5 \%$ with mean ferritin value $918.19 \pm 281.77 \mathrm{ng} / \mathrm{mL}$ (Table 1).

Mean serum Ferritin $(793 \pm 232 \mathrm{ng} / \mathrm{mL})$ was reported to be high among the poorly controlled (HbA1c > 7.1) compared to well controlled (HbA1c $<7$ ) diabetic Covid-19 cases $(403 \pm 300 \mathrm{ng} / \mathrm{mL})$ with statistically significant positive correlation (Table 5) and (Figures 5 and 6). It is also observed that the serum ferritin value increases with increase in HbA1c level in diabetic Covid-19 cases with statistically significant positive correlation (Table 1).
Correlation analysis of serum ferritin with diabetic profile parameters in diabetic COVID-19 cases revealed that there was a moderate positive correlation between serum ferritin and FBS $(\mathrm{r}=+0.55)$, PPBS $(\mathrm{r}=+0.50)$, and RBS $(\mathrm{r}=+0.46)$ which was found to be statistically significant $(\mathrm{p}<0.05)$, however, the correlation between age $(\mathrm{r}=0.09)$ and serum ferritin was not statistically significant (Table 6).

Among non-diabetic COVID-19 controls, there was a statistically significant $(\mathrm{P}<0.05)$ positive weak linear correlation between serum ferritin and age $(r=0.166)$, PPBS $(\mathrm{r}=0.107)$, and RBS $(\mathrm{r}=0.20)$. The weak linear positive correlation between FBS ( $\mathrm{r}=0.068)$ and serum ferritin was not statistically significant $(\mathrm{P}>0.05)$ (Table 7 ).

\section{DISCUSSION}

COVID-19 respiratory infection being very contagious and is prevalent in diabetics who are prone for infections easily. COVID-19 patients rapidly progress to metabolic acidosis, coagulopathy, acute respiratory failure, and septic shock. Early identification of risk factors for worsening of the disease is very vital in the treatment and prognosis of the COVID-19 disease. Diabetes and its associated factors such as increased age, comorbidities, poor diabetic control, and hyperferritinemia in the affected COVID-19 individuals will add to the problem. Qin et al., in their cohort, observed at least one underlying disorder (hypertension, diabetes, and chronic obstructive pulmonary disease) in severe cases compared to mild cases. ${ }^{18}$

Studies show that in severe COVID-19 infection, there will be not only pulmonary but also there will be systemic inflammatory response with raised serum levels of several inflammatory markers including serum ferritin which ultimately result in cytokine storm. Diabetics have elevated serum levels of ferritin, ${ }^{12,19}$ so they are more likely to encounter severe complications during COVID-19 infection as viral infections can also increase inflammation in people with diabetes.

Innumerable studies are carried out during this pandemic to understand the various aspects of this deadly disease. Due to high mortality and morbidity of COVID-19 infection, search of various and better hematological and biochemical parameter was carried out to assess the severity 
Table 5: Correlation between serum ferritin and HbA1c among well controlled and poorly controlled diabetic COVID-19 cases $(n=425)$

\begin{tabular}{lccccc}
\hline HbA1C $\%$ range & $\mathbf{n}(\%)$ & Mean \pm SD HbA1C $\%$ & Serum ferritin $(\mathbf{n g} / \mathbf{m L})$ & Pearson's correlation $\mathbf{r}$ value & P-value \\
\hline Well-controlled $(<7 \%)$ & 157 & $6.46 \pm 0.32$ & $402.98 \pm 299.48$ & 0.297 & 0.0015 \\
diabetic COVID-19 cases & $(36)$ & & & 0.330 & $<0.0001$ \\
$\begin{array}{l}\text { Poorly controlled }(>7.1) \\
\text { diabetic COVID-19 cases }\end{array}$ & 268 & $8.77 \pm 1.55$ & $793.08 \pm 231.89$ & & \\
\hline
\end{tabular}

\begin{tabular}{|c|c|c|c|}
\hline Parameter & $\begin{array}{c}\text { Pearson's } \\
\text { correlation } \mathrm{r} \text { value }\end{array}$ & P-value & Interpretation \\
\hline $\begin{array}{l}\text { Age versus } \\
\text { serum ferritin }\end{array}$ & 0.09 & 0.06 & Not significant \\
\hline $\begin{array}{l}\text { FBS versus } \\
\text { serum ferritin }\end{array}$ & 0.55 & 0.00 & Significant \\
\hline $\begin{array}{l}\text { PPBS versus } \\
\text { serum ferritin }\end{array}$ & 0.50 & 0.00 & Significant \\
\hline $\begin{array}{l}\text { RBS versus } \\
\text { serum ferritin }\end{array}$ & 0.46 & 0.00 & Significant \\
\hline
\end{tabular}

\begin{tabular}{|c|c|c|c|}
\hline Parameter & $\begin{array}{c}\text { Pearson } \\
\text { correlation } r \text { value }\end{array}$ & P-value & Interpretation \\
\hline $\begin{array}{l}\text { Age versus } \\
\text { S. ferritin }\end{array}$ & 0.166 & 0.00 & Significant \\
\hline $\begin{array}{l}\text { FBS versus } \\
\text { S. ferritin }\end{array}$ & 0.068 & 0.11 & Not Significant \\
\hline $\begin{array}{l}\text { PPBS } \\
\text { versus S. } \\
\text { ferritin }\end{array}$ & 0.107 & 0.01 & Significant \\
\hline $\begin{array}{l}\text { RBS } \\
\text { versus S. } \\
\text { ferritin }\end{array}$ & 0.200 & 0.00 & Significant \\
\hline
\end{tabular}

and prognosis of the disease. This study will give an insight into the role of inflammatory marker serum ferritin and diabetic profile parameters in COVID-19 infection in diabetics and non-diabetics.

In this study, males were more affected by COVID-19 infection (cases 57\% and controls 63.5\%). In other similar studies, male preponderance was observed. Fan et al., observed male preponderance in their study. ${ }^{20}$

In the present study, COVID-19 infection was seen to be more prevalent in the age group of 30-70 years in diabetic COVID-19 cases and 20-70 years in nondiabetic COVID-19 controls. The mean age of the study participants was significantly $(\mathrm{P}<0.05)$ high among diabetic cases $(52.89 \pm 14$ years) compared to non-diabetic

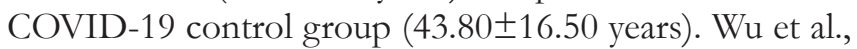
and Qin et al., in their study concluded that increasing age with comorbidities is the risk factor for contracting acute respiratory distress syndrome and death due to decreased immune response. ${ }^{18,21}$ Thus, the age factor will be the additional risk factor for the bad prognosis in diabetic COVID-19 individuals. Zhou et al., ${ }^{22}$ observed that old age was associated with more ICU admissions. Bozkurt et al., also observed high number of elderly diabetic individuals amongst severe COVID-19 patients. ${ }^{23}$

In this study, the correlation between age $(r=0.09)$ and serum ferritin was not statistically significant in cases. However, among non-diabetic controls, there was statistically significant $(\mathrm{P}<0.05)$ positive weak linear correlation observed between serum ferritin and age $(\mathrm{r}=0.166)$.

In the present study, serum levels of diabetic profile parameters (FBS, PPBS, RBS, and HbA1c) were significantly $(\mathrm{P}<0.05)$ high in cases when compared to controls. Similar result was found by Rawat et al. ${ }^{24}$ In the present study, statistically significant high levels of HbA1c were observed in cases compared to controls. Liu et al., observed patients with high $\mathrm{HbA1c}(\geq 6.5 \%)$ or fasting glucose level $(\geq 126 \mathrm{mg} / \mathrm{dl})$ on admission had increased risk of mortality. ${ }^{25}$

Statistically significant increased levels of serum ferritin level were observed in this study as the HbA1c level increased in cases. Statistically significant high levels of serum ferritin were also seen in poorly controlled diabetic COVID-19 cases compared to well-controlled diabetic COVID-19 cases. Correlation analysis among diabetic COVID-19 cases and non-diabetic COVID-19 controls indicates that serum ferritin level increases as the glucose level increases in the body.

Literature search regarding glucose metabolism in COVID-19 individuals shows that hyperglycemia promotes SARS-CoV-2 replication in human monocytes, resulting in increased viral proliferation Codo et al. ${ }^{26}$ Thus, hyperglycemia is an independent risk factor for frequent occurrence of COVID-19 infection in diabetic individuals. In diabetic MERS-CoV-infected animal (mice) studies, extensive lung pathology was observed due to dysregulated immune response, Kulcsar et al. ${ }^{27}$ Lim et al., ${ }^{28}$ also observed severe lung involvement in COVID-19 patients with poor glycemic control. Hence, hyperglycemia may be the cause 
for severe COVID-19 infection and increased need of hospitalization, ICU care, and increased mortality and morbidity. SARS-CoV-2 replication also produces more mitochondrial reactive oxygen species and activation of hypoxia-inducible factor $1 \alpha .^{29}$ Therefore, patients with diabetes mellitus typically fall into higher categories of SARS-CoV-2 infection severity than those without ${ }^{21,30}$ and poor glycemic control predicts an increased need for medications and hospitalizations, and increased mortality. ${ }^{31}$

Patients with iron overload have high ferritin levels. Increased accumulation of iron affects insulin synthesis and secretion in the pancreas and interferes with the insulin extracting capacity of the liver. Conversely, insulin stimulates cellular iron uptake through increased transferrin receptor externalization. Excessive iron accumulation can induce organic damage that leads to diabetes. ${ }^{32-34}$ Thus, insulin and iron can mutually potentiate their effects, leading, after a vicious cycle, to insulin resistance and diabetes. ${ }^{35-37}$

Ferritin is an inflammatory marker located in heart, liver, kidney, spleen, and intestinal mucosal cells but it is unclear whether serum ferritin reflects or causes inflammation, or whether it is involved in an inflammatory cycle. Kell et al., found that serum ferritin arises from damaged cells and is thus a marker of cellular damage. ${ }^{38}$

Ferritin has no circadian rhythm and completely taken up by liver. Ferritin has more expression time than other inflammatory markers such as IL- 6 and IL-10, hence, it is better predictor of disease progression. ${ }^{39}$

Results of this study showed were significantly higher levels of serum ferritin in the cases compared to controls $(\mathrm{P}<0.05)$. Serum levels of ferritin, an iron storing protein increases during COVID-19 infection. The inflammatory cytokines produced during cytokine storm stimulate the hepatocytes, macrophages, and Kupffer cells to secrete ferritin..$^{39-41}$

The alterations of the immune regulation appear to be the cause for advancement of disease from an asymptomatic or mild infection to a severe disease with poor prognosis. Ferritin, in particular under severe hyperferritinemia, is a key mediator of immune dysregulation through direct immune suppressive and pro-inflammatory effects, leading to cytokine storm. ${ }^{42}$ Several studies suggest that increased levels of serum ferritin and other inflammatory markers in severe and critical patients as compared to mild and moderate patients. ${ }^{18,43-45}$ In a retrospective cohort study from Wuhan, China, Terpo et al., reported increased ferritin and $\mathrm{LDH}$ as risk factors for acute respiratory distress syndrome, ICU support, and mortality. ${ }^{46}$
Bozkurt et al., ${ }^{23}$ observed high levels of serum ferritin in severe COVID-19 patients compared to mild COVID-19 patients. A meta-analysis conducted by Cheng et al.,47 concluded that hyperferritinemia predicts poor prognosis and worsening of COVID-19.

The previous studies interpret that hyperglycemia and hyperferritinemia individually are independent risk factor for the increased severity of COVID-19 infection. Presence of both the risk factors together in a COVID-19 individual worsens the situation. This will alarm the addition of serum ferritin estimation not only in diabetic COVID-19 individuals but also in non-diabetic COVID-19 individuals.

To summarize, the COVID-19 caused by the SARS-CoV-2 is characterized by a human-to-human transmission. Hyperglycemia promotes viral replication and prone for viral infection. Increased serum ferritin level following COVID-19 infection adds on to the problem. Vulnerability of diabetics for infection, associated hyperferritinemia makes diabetes, the major risk factor for fatal outcome in COVID-19. Hyperferritinemia leads to multiorgan

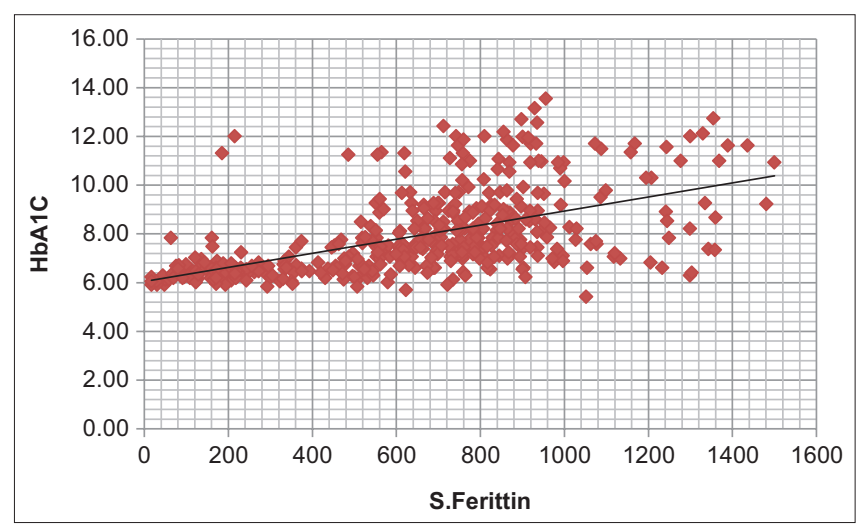

Figure 3: Scatter diagram showing correlation between serum ferritin and glycated hemoglobin in diabetic COVID-19 cases

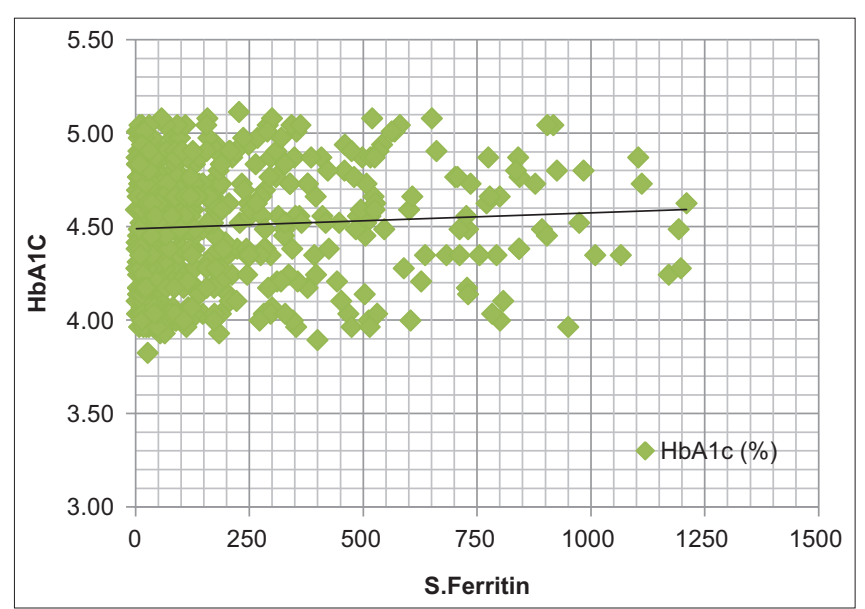

Figure 4: Scatter diagram showing correlation between serum ferritin and glycated hemoglobin among non-diabetic COVID-19 controls 


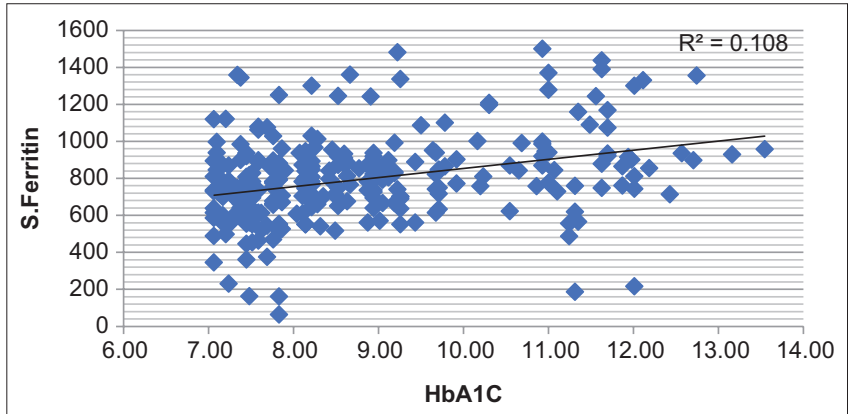

Figure 5: Correlation between serum Ferritin and $\mathrm{HbA1c}$ among well controlled Diabetic cases $(\mathrm{N}=425)$

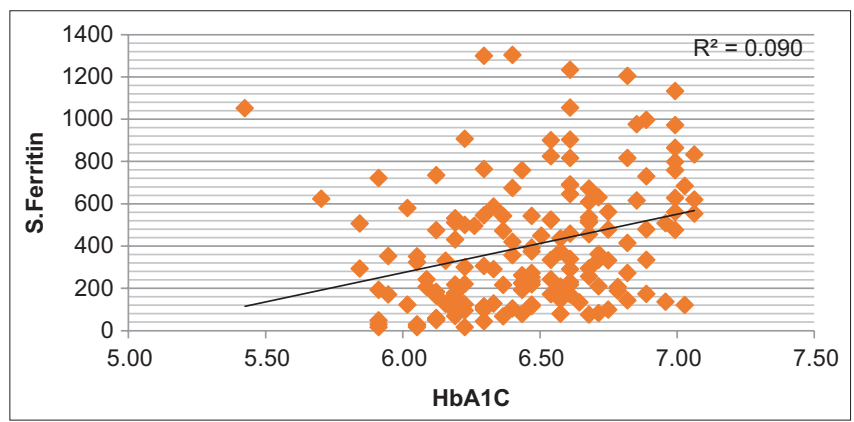

Figure 6: Correlation between serum ferritin and $\mathrm{HbA} 1 \mathrm{c}$ among poorly controlled diabetic cases $(n=425)$

damage and increases the severity of infection. Increased age with decreased immune regulation is an additional risk factor for corona infection. These multiple factors together increase mortality and morbidity of COVID-19 infection. Serum ferritin can be considered as a valuable biomarker to screen the diabetic and non-diabetic for the presence of hyperinflammation and to predict severity of COVID-19 infection so that it will help to prevent end-organ damage.

\section{Limitations of the study}

COVID-19 patients were not categorized in to mild, moderate, and severe. Other inflammatory markers were also not measured.

\section{CONCLUSION}

Hyperferritinemia is prevalent in diabetic COVID-19 individuals. Hence, the estimation of inflammatory biomarker serum ferritin may be considered for the early prediction of severity of COVID-19 infection, guiding the clinician for proper management of COVID-19 patients and helping in reducing the disease morbidity and mortality.

\section{ACKNOWLEDGMENT}

Sincere thanks to the patients involved in the study and the faculties of the Department of Biochemistry and Department of Community Medicine, RRMCH, Bengaluru.

\section{REFERENCES}

1. WHO Director-General's Opening Remarks at the Media Briefing on COVID19-March 2020; 2020.

2. Guan WJ, Ni ZY and Hu Y. Clinical characteristics of Coronavirus disease 2019 in China. N Engl J Med. 2020;382:1708-1720.

3. Gralinski LE and Menachery VD. Return of the Coronavirus: 2019-nCoV. Viruses. 2020;12:135.

https://doi.org/10.3390/v12020135

4. Kluge $\mathrm{HH}$. WHO Regional Director for Europe Copenhagen; 2020. Available from: http://www.who.int. [Last accessed on 2020 Jun 25].

5. Valdez R, Liu T, Yoon PW and Khoury MJ. Family history and prevalence of diabetes in the U.S. population: The 6-year results from the national health and nutrition examination survey (19992004). Diabetes Care. 2007;30(10):2517-2522. https://doi. org/10.2337/dc07-0720

6. Maddaloni E and Buzzetti R. COVID-19 and diabetes mellitus: Unveiling the interaction of two pandemics. Diabetes Metab Res Rev. 2020;36:e33213321.

https://doi.org/10.1002/dmrr.3321

7. Zhu N, Zhang D, Wang W, Li X, Yang B, Song J, et al. A novel Coronavirus from patients with pneumonia in China, 2019. N Engl J Med. 2020;382(8):727-733.

8. Yang J, Zheng Y, Gou X, Pu K, Chen Z, Guo Q, et al. Prevalence of comorbidities and its effects in patients infected with SARSCoV-2: A systematic review and meta-analysis. Int J Infect Dis. 2020;94:91-95.

https://doi.org/10.1016/j.ijid.2020.03.017

9. Hu Y, Sun J, Dai Z, Deng H, Li X, Huang Q, et al. Prevalence and severity of corona virus disease 2019 (COVID-19): A systematic review and meta-analysis. J Clin Virol. 2020;127:104371. https://doi.org/10.1016/j.jcv.2020.104371

10. Guo W, Li M, Dong Y, Zhou H, Zhang Z, Tian C, et al. Diabetes is a risk factor for the progression and prognosis of COVID-19. Diabetes Metab Res Rev. 2020;2020:e3319. https://doi.org/10.1002/dmrr.3319

11. Abbaspour N, Hurrell $R$ and Kelishadi R. Review on iron and its importance for human health. J Res Med Sci. 2014;19(2):164-174.

12. Son NE. Influence of ferritin levels and inflammatory markers on $\mathrm{HbA} 1 \mathrm{c}$ in the Type 2 diabetes mellitus patients. Pak J Med Sci. 2019;35(4):1030-1035.

https://doi.org/10.12669/pjms.35.4.1003

13. Roglic $G$ and Unwin N. Mortality attributable to diabetes: Estimates for the year 2010. Diabetes Res Clin Pract. 2010;87(1):15-19. https://doi.org/10.1016/j.diabres.2009.10.006

14. IDF. IDF Diabetes Atlas, 2013. $6^{\text {th }}$ ed., Ch. 2.1. Brussels, Belgium: IDF; 2013. p. 34.

15. Kam JP, Ho S, Herrera $Y$ and Jean R. Clinical outcomes in diabetic vs non-diabetic patients with severe COVID-19. Chest. 2020;158(4):A688. https://doi.org/10.1016/j.chest.2020.08.647

16. Wang F, Yang Y, Dong K, Yan Y, Zhang S, Ren H, et al. Clinical characteristics of 28 patients with diabetes and COVID-19 in Wuhan, China. Endocr Pract. 2020;26(6):668-674.

17. Li Y, Li Y, Han X, Alwalid O, Cui Y, Cao Y, et al. Baseline characteristics and risk factors for short-term outcomes in 132 
COVID-19 patients with diabetes in Wuhan China: A retrospective study. Diabetes Res Clin Pract. 2020;166:108299.

https://doi.org/10.1016/j.diabres.2020.108299

18. Qin C, Zhou L, Hu Z, Zhang S, Yang S, Tao Y, et al. Dysregulation of immune response in patients with Coronavirus 2019 (COVID-19) in Wuhan, China. Clin Infect Dis. 2020;71(15):762-768. https://doi.org/10.1093/cid/ciaa248

19. Momeni A, Behradmanesh MS, Kheiri S and Abasi F. Serum ferritin has correlation with $\mathrm{HbA} 1 \mathrm{c}$ in Type 2 diabetic patients. Adv Biomed Res. 2015;4:74. https://doi.org/10.4103/2277-9175.153900

20. Fan BE, Chong VL, Chan SW, Lim GH, Lim KG, Tan GB, et al. Hematologic parameters in patients with COVID-19 infection. Am J Haematol. 2021;95:E131-E134.

21. Wu C, Chen X, Cai $Y$, Xia J, Zhou X, Xu S, et al. Risk factors associated with acute respiratory distress syndrome and death in patients with Coronavirus disease 2019 pneumonia in Wuhan, China. JAMA Intern Med. 2020;180(7):934-943.

https://doi.org/10.1001/jamainternmed.2020.0994

22. Zhou F, Yu T, Du R, Fan G, Liu Y, Liu Z, et al. Clinical course and risk factors for mortality of adult inpatients with COVID-19 in Wuhan, China: A retrospective cohort study. Lancet. 2020;395(10229):1054-1062.

https://doi.org/10.1016/s0140-6736(20)30566-3

23. Bozkurt FT, Tercan M, Patmano G, Tanrıverdi TB, Demir HA and Yurekli UF. Can ferritin levels predict the severity of illness in patients with COVID-19? Cureus. 2021;13(1):e12832.

https://doi.org/10.7759/cureus.12832

24. Rawat N, Mathur N, Harikrishnan R, Choudhary J, Rawat K and Mathur M. A study of correlation of serum ferritin with glycated haemoglobin in diabetes mellitus Type 2 patients: A case control study. Asian Pac J Health Sci. 2016;3(4):83-88.

https://doi.org/10.21276/apjhs.2016.3.4.13

25. Liu Y, Lu R, Wang J, Cheng Q, Zhang R, Zhang S, et al. Diabetes, even newly defined by $\mathrm{HbA} 1 \mathrm{c}$ testing, is associated with an increased risk of in-hospital death in adults with COVID-19. BMC Endocr Disord. 2021;21(1):56.

https://doi.org/10.1186/s12902-021-00717-6

26. Codo AC, Davanzo GG, Monteiro LB, de Souza GF, Muraro SP, Virgilio-da-Silva JV, et al. Elevated glucose levels favour SARSCoV-2 infection and monocyte response through a HIF-1 $\alpha$ / glycolysis-dependent axis. Cell Metab. 2020;32(3):437-446. https://doi.org/10.2139/ssrn.3606770

27. Kulcsar KA, Coleman CM, Beck SE and Frieman MB. Comorbid diabetes results in immune dysregulation and enhanced disease severity following MERS-CoV infection. JCl Insight. 2019;4(20):e131774.

https://doi.org/10.1172/jci.insight.131774

28. Lim S, Bae JH, Kwon HS and Nauck MA. COVID-19 and diabetes mellitus: From pathophysiology to clinical management. Nat Rev Endocrinol. 2021;17(1):11-30. https://doi.org/10.1038/s41574-020-00435-4

29. Yang JK, Feng Y, Yuan MY, Yuan SY, Fu HJ, Wu BY, et al. Plasma glucose levels and diabetes are independent predictors for mortality and morbidity in patients with SARS. Diabet Med. 2006;23(6):623-628.

https://doi.org/10.1111/j.1464-5491.2006.01861.x

30. Carey IM, Critchley JA, DeWilde S, Harris T, Hosking FJ and Cook DG. Risk of infection in Type 1 and Type 2 diabetes compared with the general population: A matched cohort study. Diabetes Care. 2018;41(3):513-521.

https://doi.org/10.2337/dc17-2131
31. Critchley JA, Carey IM, Harris T, DeWilde S, Hosking FJ and Cook DG. Glycemic control and risk of infections among people with Type 1 or Type 2 diabetes in a large primary care cohort study. Diabetes Care. 2018;41(10):2127-2135. https://doi.org/10.2337/dc18-0287

32. Niederau C, Berger M, Stremmel W, Starke A, Strohmeyer G and Ebert R. Hyperinsulinemia in non-cirrhotic haemochromatosis: impaired hepatic insulin degradation. Diabetology. 1984;26(6):441-444. https://doi.org/10.1007/bf00262217

33. Dandona P, Hussain MA, Varghese Z, Politis D, Flynn DM and Hoffbrand AV. Insulin resistance and iron overload. Ann Clin Biochem. 1983;20:77-79. https://doi.org/10.1177/000456328302000203

34. Shafer Al, Cheron RG, Dluhy R, Cooper B, Gleason RE and Soeldner JS. Clinical consequences of acquired transfusional iron overload in adults. N Engl J Med. 1981;304(6):319-324. https://doi.org/10.1056/nejm198102053040603

35. Davis RJ, Corvera S and Czech MP. Insulin stimulates cellular iron uptake and causes the redistribution of intracellular transferrin receptors to the plasma membrane. J Biol Chem. 1986;261(19):8708-8711.

https://doi.org/10.1016/s0021-9258(19)84438-1

36. Yokomori N, Iwasa $\mathrm{Y}$, Aida $\mathrm{K}$, Inoue $\mathrm{M}$, Tawata $\mathrm{M}$ and Onaya $\mathrm{T}$. Transcriptional regulation of ferritin messenger ribonucleic acid levels by insulin in cultured rat glioma cells. Endocrinology. 1991;128(3):1474-1480.

https://doi.org/10.1210/endo-128-3-1474

37. Tanner LI and Lienhard GE. Localization of transferrin receptors and insulin like growth factor II receptors in vesicles from 3T3-L1 adipocytes that contain intracellular glucose transporters. J Cell Biol. 1989;108(4):1537-1545.

https://doi.org/10.1083/jcb.108.4.1537

38. Kell DB and Pretorius E. Serum ferritin is an important inflammatory disease marker, as it is mainly a leakage product from damaged cells. Metallomics. 2014;6(4):748-773. https://doi.org/10.1039/c3mt00347g

39. Ridefelt $P$, Larsson A, Rehman JU and Axelsson J. Influences of sleep and the circadian rhythm on iron-status indices. Clin Biochem. 2010;43(16-17):1323-1328.

https://doi.org/10.1016/j.clinbiochem.2010.08.023

40. Muntanerelat J, Ourlin JC, Domergue J and Maurel P. Differential effects of cytokines on the inducible expression of CYP1A1, CYP1A2, and CYP3A4 in human hepatocytes in primary culture. Hepatology. 1995;22(4):1143-1153. https://doi.org/10.1016/0270-9139(95)90622-3

41. Tran TN, Eubanks SK, Schaffer KJ, Zhou CY and Linder MC. Secretion of ferritin by rat hepatoma cells and its regulation by inflammatory cytokines and iron. Blood. 1997;90(12):4979-4986. https://doi.org/10.1182/blood.v90.12.4979.4979_4979_4986

42. Khalil UA, Seliem FO, Alnahal A, Awad M, Sadek AM and Fawzy MS. Association of serum ferritin with insulin resistance in offsprings of Type 2 diabetics. Egypt $\mathrm{J}$ Intern Med. 2018;30: 13-27. https://doi.org/10.4103/ejim.ejim_70_17

43. Liu J, Li S, Liu J, Liang B, Wang X, Wang H, et al. Longitudinal characteristics of lymphocyte responses and cytokine profiles in the peripheral blood of SARS-CoV-2 infected patients. EBiomedicine. 2020;55:102763.

44. Lin Z, Long F, Yang Y, Chen X, Xu L and Yang M. Serum ferritin as an independent risk factor for severity in COVID-19 patients. J Infect. 2020;81(4):647-679. 
https://doi.org/10.1016/j.jinf.2020.06.053

45. Wang W, Knovich MA, Coffman LG, Torti FM and Torti SV. Serum ferritin: Past, present and future. Biochim Biophys Acta. 2010;1800(8):760-769. https://doi.org/10.1016/j.bbagen.2010.03.011

46. Terpos E, Ntanasis-Stathopoulos I, Elalamy I, Kastritis E, Sergentanis TN, Politou M, et al. Hematological findings and complications of COVID-19. Am J Hematol. 2020;95(7):834-847. https://doi.org/10.1002/ajh.25829

47. Cheng L, Li H, Li L, Liu C, Yan S, Chen H and Li Y. Ferritin in the Coronavirus disease 2019 (COVID-19): A systematic review and meta-analysis. J Clin Lab Anal. 2020;34(10):e23618.

https://doi.org/10.1002/jcla.23618

\section{Authors Contribution:}

BCM-Concept and design of the study, prepared first draft of manuscript; MK- Concept, interpreted the results; reviewed the literature and manuscript preparation; SAC-Concept, statistical analysis, and interpretation; and RR-Concept, coordination, preparation of manuscript, and revision of the manuscript.

\section{Work attributed to:}

Rajarajeswari Medical College and Hospital, Bengaluru - 560 078, Karnataka, India.

\section{Orcid ID:}

Mr. Mukesh Kumar - (1) https://orcid.org/0000-0002-8973-8559

Dr. Bindu CM - (i) https://orcid.org/0000-0003-1160-0899

Dr. Shyam AC - (i) https://orcid.org/0000-0001-5818-5122

Dr. Reena R - io https://orcid.org/0000-0003-0646-3877 